\title{
Teaching Information Literacy in Nursing Using Blended Learning Pedagogy
}

\author{
Shwu-Ru Liou, Wei-Chieh Yu, Hsiu-Min Tsai, Ching-Yu Cheng* \\ College of Nursing, Chang Gung University of Science and Technology, Chiayi, Taiwan \\ Email: ${ }^{*}$ chingyuus@gmail.com
}

Received 27 June 2015; accepted 2 August 2015; published 5 August 2015

Copyright (C) 2015 by authors and Scientific Research Publishing Inc.

This work is licensed under the Creative Commons Attribution International License (CC BY). http://creativecommons.org/licenses/by/4.0/

(c) (i) Open Access

\begin{abstract}
Information literacy is a crucial skill for nurses to retrieve, judge, and provide appropriate information to patients and their caregivers. This study aimed to develop a blended course to cultivate nursing students' informatics competency. This was a three-semester study including a development of the course, pilot-test and modification of the course design, and final implementation of the modified course design. Almost all class activities were done online except for periodical meetings for problem discussions. Information literacy definition, tool literacy, resource literacy, social literacy, research literacy, publishing literacy, and critical literacy were included in the course curriculum. Twenty-one and 18 students enrolled in the first and third semester of the study. Those students were invited to complete a survey consisting of 25 Likert-scale questions that asked about perception of blended-learning/teaching strategy, effectiveness of the blended course, and what was learned at the conclusion of the course. The majority of students perceived positively toward the teaching strategies, expressed that they understood more about information literacy, and presented abilities in applying information literacy skills in nursing. Structure of the course can be used to cultivate and improve nursing students' competency in informatics. The teaching model can be used in future online courses.
\end{abstract}

\section{Keywords}

Blended-Learning, Information Literacy, Informatics Competency, Nursing

\section{Introduction}

Many experts asserted that informatics competencies would be a fundamental building block and computer technology being an essential part of professional nursing practice (McNeil et al., 2003). As computer technol-

"Corresponding author.

How to cite this paper: Liou, S.-R., Yu, W.-C., Tsai, H.-M., \& Cheng, C.-Y. (2015). Teaching Information Literacy in Nursing Using Blended Learning Pedagogy. Creative Education, 6, 1446-1455. http://dx.doi.org/10.4236/ce.2015.613145 
ogy evolves at an incredibly rapid pace, it is increasingly important to recognize the role not only of such technology in education but also of information technology in the nursing curriculum. Association of College and Research Libraries defined information literacy as "a set of abilities requiring individuals to recognize when information is needed and have the ability to locate, evaluate, and use effectively the needed information" (Association of College \& Research Libraries, 2000). Healthcare organizations, policy makers and researchers have identified information technology and information literacy of the users as key to improve quality and efficiency of care and reduce medical errors (Fetter, 2009b). Such safe and effective practice requires of adequate access and the ability to synthesize information (Barnard, Nash, \& O'Brien, 2005).

Healthcare has been an information intensive industry where timely and quality information is critical resources. It is also one of the early adopters of using technology to provide educational support. Nurses are the vast users of information and communication technology (ICT) in this specialized field. To allow the available technology to reach its potential, skills and abilities must be built into nursing curricula so that once employed, the graduates possess the necessary skills to maintain specific knowledge and engage in lifelong professional development (Eley, Fallon, Soar, Buikstra, \& Hegney, 2008). Bruce (2004) noted that curricula which provided opportunities and facilitated the learning of specific skills and required ongoing application of new (clinical) knowledge were more likely to be successful. Development of competencies in information literacy enables nursing professionals to take responsibilities for continuous learning over a career life time. Unfortunately, in the past years, efforts to raise students' knowledge and performance beyond basic level of informatics have had minimal success (Fetter, 2009a), due to the fact that experts and school officials could not agree on effective strategies for nursing education and teaching nursing information literacy. As a result, the contrast between the access and the availability of relevant information is evident.

Educators have been faced challenges with a changing student population, who are younger than 25 years of age (born after 1988). These "digital natives" have been known to be technology savvy. They respond to information technology much more sufficiently and effectively and their desire to learn using interactive means is stronger than that of the "old scholar" (equal or older than 25 years old) (Skiba, Connors, \& Jeffries, 2008). In other words, traditional lectures are in need of more pervasive ways of teaching and learning.

To create a nursing workforce able to access and effectively use an information system, and to "recognize, solve information problems and learn from the resources" (Barnard et al., 2005) are the center as well as the foundation for critical thinking in professional development courses. However, only a few accounted for innovative teaching strategies in the published literature about information literacy from the Asian countries (Saranto \& Hovenga, 2004). In western countries, some published articles presented or suggested strategies of integrating information literacy in nursing curriculum (Carruth, Broussard, Waldmeier, Gauthier, \& Mixon, 2010; Edwards \& O’Connor, 2011; Fetter, 2009b; Flood, Gasiewics, \& Delpier, 2010; Patterson, Carter-Templeton, \& Russell, 2009; Stombaugh, Sperstad, Van Wormer, \& Jennings, 2013). Excluding traditional lecture teaching, online teaching/learning and blended-learning strategy have been applied. In addition to achieving same learning outcomes (Edwards, Kitzmiller, \& Breakenridge-Sproat, 2012; Sherman, Comer, Putnam, \& Freeman, 2012), online teaching/learning breaks the limitation of time and space and enables flexible learning, communication, and participation (Fedynich, 2014). Especially, learners in blended course benefited from self-pacing and flexibility in learning, interaction with other learners and teachers, repeated access to information, and clarification in discussion with others (Sherman et al., 2012). Blended course is therefore worth developed.

This paper describes the development of a blended-learning information literacy course aimed to cultivate nursing students' informatics competencies. Specific concerns were placed upon how this designed pedagogy helped shape the foundation of the information literacy of the learners. Students were expected to exercise knowledge and related skills in nursing informatics during/upon the completion of the course. In addition, since the course is provided in a non-English speaking country and English is a global language and many articles and information are provided in English, the course is taught in English to increase students' ability in English. Research questions guided this study included: 1) Do students' information literacy competencies increase after the implementation of the course? 2) What is students' perception about the developed pedagogy?

\section{Method}

This study was a three-semester design, which included the development of the course, pilot-test (Fall semester, 2011) and modification of the course design (Spring semester, 2012), and final implementation of the modified 
course design (Fall semester, 2012). Students’ perceptions about the course were explored using a questionnaire and qualitative interviews. Part of the study results, primarily the ones from the initial phase of the course, was presented at the 2013 International Conference on Advanced Information and Communication Technology for Education (ICAICTE 2013). This paper expanded and built upon the previous preliminary analyses by reporting the findings of the entire study.

\subsection{Design of the Course Structure}

Information searching is not the only focus of information literacy, content of information, information communication, analysis of information, and evaluation on information are also parts of information literacy (Committee on Information Technology Literacy, 1999). To have a holistic view of information literacy and gain those abilities, the curriculum's content, structure, and sequence should include the concept and skills of information literacy (Association of College \& Research Libraries, 2000). While designing the course, the standards for information literacy competency for higher education proposed by the Association of College and Research Libraries were used as the objectives of the course. The standards include "determine the extent of information needed; access the needed information effectively and efficiently; evaluate information and its sources critically; incorporate selected information into one's knowledge base; use information effectively to accomplish a specific purpose; and understand the economic, legal, and social issues surrounding the use of information and access and use information ethically and legally” (Association of College \& Research Libraries, 2000).

To achieve those objectives, we structured the course units based on the dimensions of information literacy that included tool/emerging technology literacy, resource literacy, social-structural literacy, research literacy, publishing literacy, and critical literacy (Shapiro \& Hughes, 1996) (Figure 1) and incorporated standards of information literacy competency into class assignments.

\subsection{Design of the Course Teaching Mode}

At the initial stage, a team consisting of faculty members was established to design the course. They read literature about informatics and discussed periodically to achieve a consensus of goals of the course and teaching strategies. Two members, with one specialized in nursing and the other in computer education, taught the course. Moreover, in order to increase students' global view in nursing and information, a nursing professor in the United States was invited to take part in teaching the course. Skype, an internet communication tool that allows instant messaging and group meetings, was used to communicate between the class and the faculty in the United States. The structure and topics of this 18-week blended course was based on dimensions of information literacy (Shapiro \& Hughes, 1996) and is shown in Figure 1. To achieve information literacy competency for higher education proposed by the Association of College and Research Libraries (2000), the objectives of the course were set as:

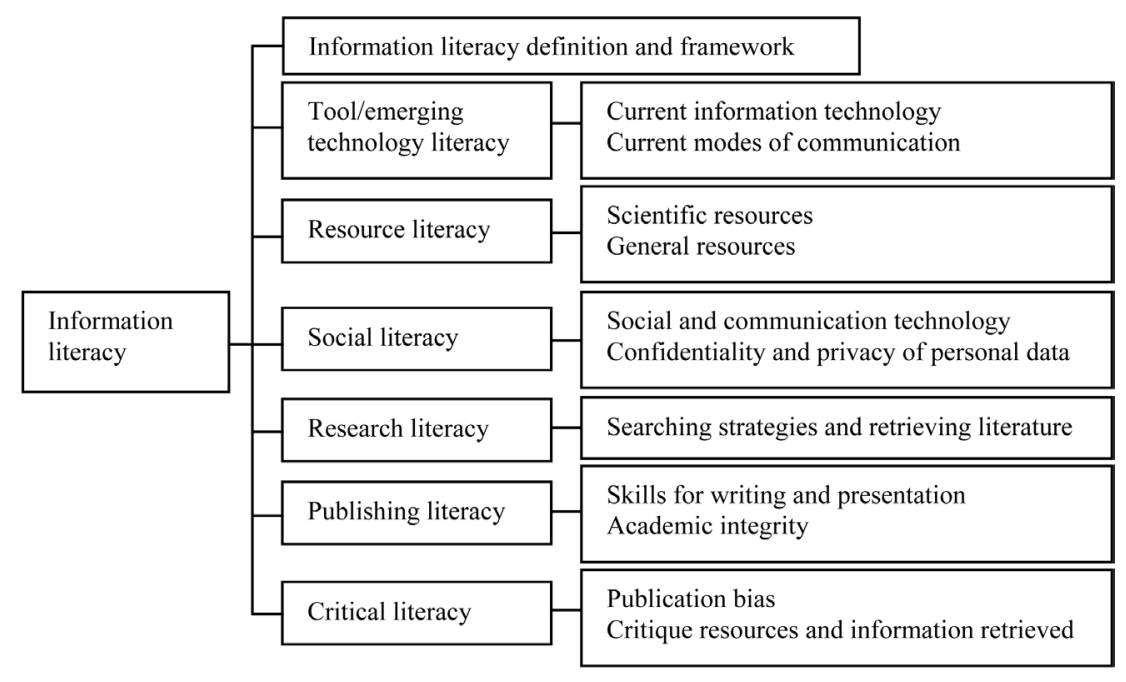

Figure 1. Structure of the course. 
1) Be familiar with course management software such as E-campus.

2) Understand what information literacy is and its framework.

3) Explain various terminologies related to information technology.

4) Be familiar with how information technology can be used in education-teaching using technology, teaching about technology and administrative purposes.

5) Develop the skills to obtain e-books, e-journals, and other meaningful information using the library or the Internet.

6) Demonstrate abilities and gain proficiency in search of information, management of information, and application of various technological tools in presenting information.

7) Develop skills to critique/evaluate software, hardware and websites.

8) Develop an awareness of problems related to computer and information ownership.

The majority of the classes were conducted online while some classes were completed using real-time online discussion. In addition, students and the instructors met periodically for mini-lectures, clarification or problem discussions. E-campus, a school-wide electronic course management platform, was used for this course. The platform includes sections of class information, bulletin board, class unit/note, assignment, discussion board, quiz, and questionnaire. The instructors set up the course before the semester began and updated all materials including announcements periodically. Students were required to self-learn course materials, discuss raised issues online, and form questions to discuss with the instructors in the face-to-face classes. Instructors summarized unit contents in the face-to-face classes depending on students' needs. Activities were designed for each class and nearly all class activities were done online. Assignments in the course included learning journals, literature search, website critiques, discussion forums on literacy issues such as academic integrity, and a final project focusing on health-related issues. Students first introduced themselves on the E-campus thus they knew each other better. Literacy issues were also discussed on the E-campus therefore students could expand the discussion based on other students' responses. All other assignments were submitted via E-campus to the instructors and the instructors' reflections/corrections on the assignments were sent back to the students via E-campus as well. At the end of the semester, students were asked to apply any presentation tools except for Microsoft Powerpoint to present their final project both in class and to the public.

Modifications of the course design were made basing on the comments of the students participating in the first semester and experts participating in the second semester. Based on suggestions, three experts in the field of communication were invited to help students gain more knowledge about skills in communication and presentation and apply the knowledge into their final projects.

\subsection{Sample}

Only senior nursing students were recruited in the study because they had to have knowledge about health and nursing in order to complete a health-related project. Also, since the course was taught entirely in English, only students who passed an entry-level English proficiency test were allowed in the course. Before the semester began, the instructors introduced the course to all senior students in the school and set up a time for students who were interested in the course to take the English proficiency exam. Twenty-one and eighteen students passed the exam and enrolled in fall semester 2011 and fall semester 2012 for the time of the study, respectively. These students had studied and passed all nursing-related courses and nursing practicum in medical, surgical, obstetrical, pediatric, psychological, and community health nursing. All students in both semesters, aging between 18 and 23, were homogenous in educational background and work experience since those students entered the research university directly after they graduated from high school. All students enrolled in the first semester were females whereas one male student enrolled in the third semester.

\subsection{Evaluation of the Course Design}

The course was evaluated at the end of the first and third semesters by asking 25 questions about students' perception of computer-facilitated learning (10 questions), effectiveness of the blended-learning class (8 questions), and what was learned after the class (7 questions). Students chose an answer from strongly agree, agree, disagree, and disagree strongly (Appendix). All questions were placed online and were answered anonymously. Students were encouraged to complete all evaluation questions. The overall response rates were $81 \%$ (17 of 21 students) and 100\% (18 of 18 students) for semester in 2011 and 2012, respectively. 
In addition to the quantitative measure, students were asked to provide their thoughts about the course design and blended-learning pedagogy by answering open-ended questions posted on E-campus at the end of the semester. Students were invited to provide comments and suggestions for the course. Sample questions included: comparing an online class to a traditional face-to-face class, what was your perception of the online class? What did you think you can truly benefit from the class? What did you suggest to make this class better?

A seminar with experts in the field of computer science, nursing, and education was held in the second semester for the purpose of modifying course design. Before the seminar, all experts were invited to attend a schoolwide end-of-semester presentation by the students. In addition, one of the instructors presented the course design and teaching strategy to the experts. Experts were asked to comment on the course design.

\subsection{Data Analysis}

Quantitative data were analyzed with frequency whereas content analysis was applied to analyze qualitative data.

\section{Results}

The majority of students possessed positive thoughts about blended-learning mode that was used throughout the course. In the first semester, fewer than $80 \%$ of the students felt that the complexity of tasks required in the course was important and thought that content covered in the course would be the same if using traditional lecture method. Based on these results, class activities and assignments were discussed among faculty members. Some activities and assignments were simplified and instructions for them were explained and clarified in face-to-face meetings; however, course contents, basic activities and assignments that were required to achieve course objectives remained intact. In the subsequent semester, the rate of agreeing the importance of the complexity of required tasks increased to over $80 \%$. However, over $20 \%$ of the students in the very same semester thought that collaborative learning was not effective (Figure 2). For the effectiveness of the online teaching, over $80 \%$ of students in both semesters perceived that the blended-learning/teaching strategy was an effective method for teaching (Figure 3). In addition, students learned what information literacy was and could apply information literacy skills in nursing after completing the course (Figure 4).

When students were asked about their perception of blended-learning/teaching, they commented that the course design was "convenient and flexible" for them to learn because they "can update information easily and timely," "can stay at home to learn," "can communicate electronically at any time with the teachers without making appointments and the trip to meet the teachers." They "would not have to worry or feel nervous about

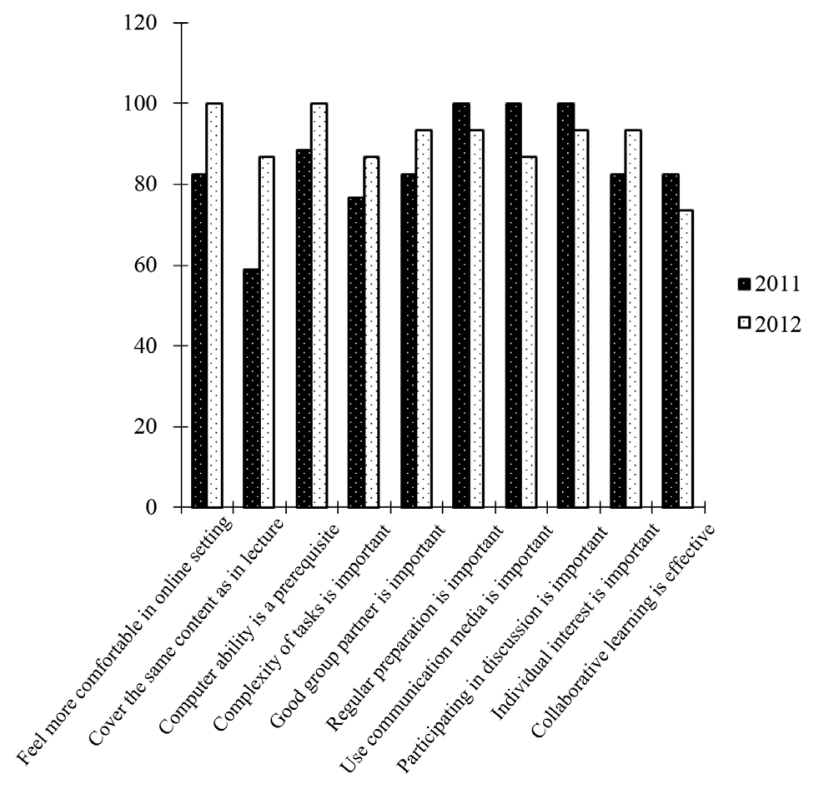

Figure 2. Students who strongly agree or agree with the blended teaching/learning. 


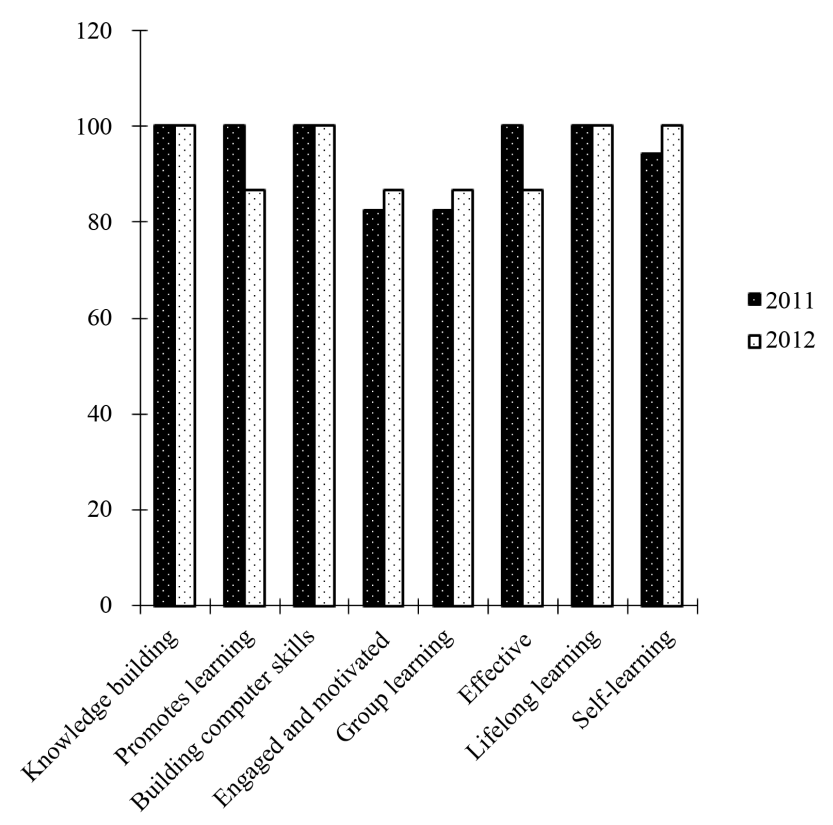

Figure 3. Students who strongly agree or agree with the effectiveness of blended teaching/learning strategy.

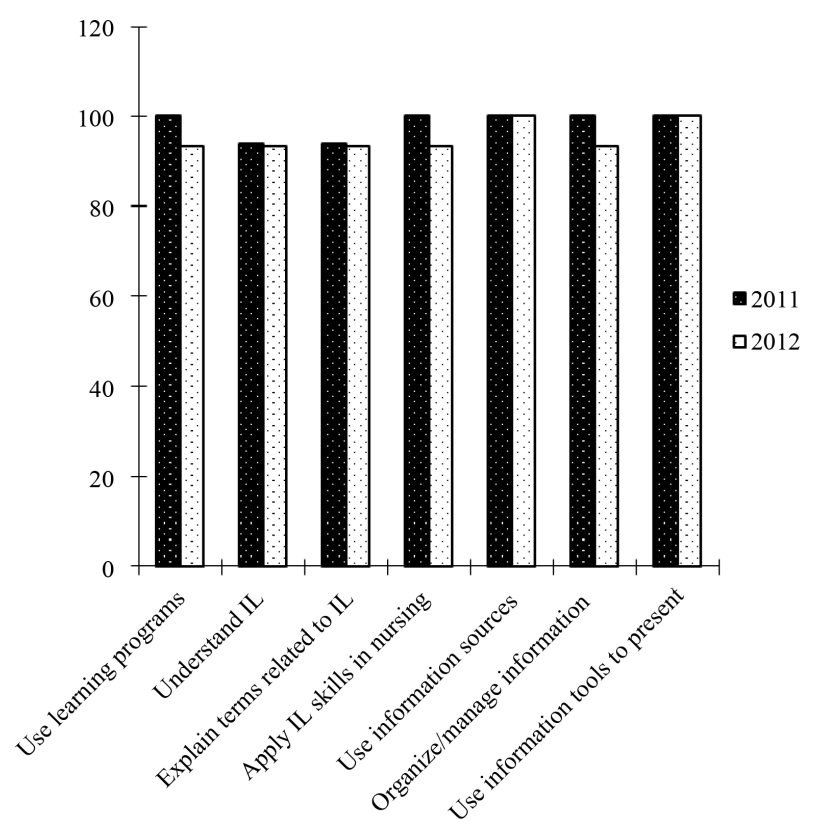

Figure 4. Information literacy that students learned from the course.

making mistakes" since discussions were done online rather than in person. In addition, their "computer skills improved" and they "knew more resources to help in learning." Learning became "more interesting and multifaceted." However, one student mentioned her "feeling of disassociation to the reality" since she "seldom met and obtained knowledge from the teachers," which was very different from other courses. Students also mentioned that this blended course design could apply to almost all other nursing courses except for advanced courses that require more extended explanations from teachers and/or courses in which hands-on nursing skills are of greatest importance. 


\section{Discussion and Conclusion}

The study was a three-semester study that included a development of the course, pilot test and modification of the course design, and final implementation of the modified course design. Two main purposes were achieved after the study: increasing students' competency in information literacy and designing a blended course. At the conclusion of the study, students not only possessed positive thoughts about the blended-learning/teaching strategy, but also understood more about information literacy and, furthermore, they could apply information literacy skills in nursing. The teaching model for information literacy developed in this study especially the structure of the course can be a reference for other educators to develop online courses and informatics courses.

As the information and internet technology advances, information overload-the amount of information exceeds the amount of information that can be handled by an individual-has become a problem. Information literacy competency, which involves retrieving, judging, managing, and using information properly, becomes a must-have skill. This competency is especially important for nurses since nurses are the main and first-line healthcare providers in the healthcare systems. In addition, the National League for Nursing and the American Association of Colleges of Nursing recommends or lists information literacy as an ability of baccalaureate graduates (American Association of Colleges of Nursing, 2008; National League for Nursing, 2008). Nursing faculty members also expressed nursing students' lack of informatics skills and the importance of information literacy competency in both academia and clinical practice (Fetter, 2008). Although information literacy competency was important and its standards have been set up for higher education (McNeil et al., 2003), there is a lack of publications about information literacy in nursing (Barnard et al., 2005) and few published articles have reported a development of information literacy nursing curriculum or blended courses (Carruth et al., 2010; Edwards \& O’Connor, 2011; Fetter, 2009b; Flood et al., 2010; Patterson et al., 2009).

To bridge the gap between students' lack of information literacy competency and the need of that competency in nursing, the design of class units and topics of the course were based on definition of information literacy and competency in information literacy for higher education. Comparing to other studies that incorporated information literacy in curriculum that taught nursing students or nurses computer skills and searching and using information (Carruth et al., 2010; Edwards \& O'Connor, 2011; Fetter, 2009a; Flood et al., 2010; Patterson et al., 2009), our course used a broader definition of information literacy. Specifically, this course introduced information resources and publication bias, information/communication technologies, ways of searching and critiquing information, safety of information, and ethics and skills for writing and presentation. Based on students' participation in classes and performance, it is suggested to use broader definition for informatics, understand specific information literacy needs in different disciplines, and design individualized curricula for different courses.

Blended-learning/teaching strategy, which was a mix of instructor-lead and technology-based teaching mode, was applied in this study. Almost all of class activities were done online except for periodical meetings for clarifications and problem discussions. A mini lecture was given in the face-to-face classes if it was needed. Similar to other studies, students in this course perceived positively about the course delivery method (Fedynich, 2014; Sherman et al., 2012). Specifically, since this course was an informatics-related course, students could practice skills in using computer and the Internet and applied what they learned in classes. Activities or assignments, which included discussion activities and a final group project, were arranged for each class and therefore a portion of the students in the pilot study thought that contents covered in the course would not be the same if traditional lecture teaching mode was used and tasks required in the course was complex. Even though students had such perceptions, they felt improvement in computer skills, knew more about information literacy, and perceived learning more interesting and multifaceted. This result supported the suggestions by other researchers (Lim, Morris, \& Kupritz, 2007) that inclusion of discussion, class assignments, and individual/group projects could increase students' effective learning.

One important issue was raised by the students. They suggested to apply the teaching strategies used in this course to other courses except for courses needed more explanations from teachers or practices. This result was similar to other studies that clinical nurses although appreciated online teaching, hoping to have more opportunities for hands-on practicing (Edwards et al., 2012). Nursing is a profession requiring proficient skills. Therefore, while considering using blended course design, it is recommended to appraise characteristics of the course and obtain a balance between practicing, face-to-face lecture and skills demonstration, and online learning.

\section{Limitation and Suggestion}

Although this study successfully designed a blended course of information literacy and improved nursing stu- 
dents' informatics competency, the study recruited only a few nursing students from within a single university. Future studies are suggested to apply the designed course to a larger class in other disciplines. Different teaching modes such as online teaching can be applied to understand a better way of teaching information literacy.

\section{Acknowledgements}

The authors acknowledge the Center for Teaching \& Learning Excellence in Northern Region, Ministry of Education (4-3-C-1) in Taiwan for funding this study. We also thank Associate Professor Lisa Brown in Virginia Commonwealth University in the United States for her help in teaching part of the course.

\section{References}

American Association of Colleges of Nursing (2008). The Essentials of Baccalaureate Education for Professional Nursing Practice. http://www.aacn.nche.edu/education-resources/BaccEssentials08.pdf

Association of College \& Research Libraries (2000). Information Literacy Competency Standards for Higher Education. Association of College \& Research Libraries, Chicago. http://www.ala.org/acrl/standards/informationliteracycompetency

Barnard, A., Nash, R., \& O’Brien, M. (2005). Information Literacy: Development Lifelong Skills through Nursing Education. Journal of Nursing Education, 44, 505-508.

Bruce, C. (2004). Information Literacy as a Catalyst for Educational Change: A Background Paper. Proceedings for the 3rd International Lifelong Learning Conference, Yeppoon, 8-19. http://eprints.qut.edu.au/4977/1/4977_1.pdf

Carruth, A. K., Broussard, P. C., Waldmeier, V. P., Gauthier, D. M., \& Mixon, G. (2010). Graduate Nursing Online Orientation Course: Transitioning for Success. Journal of Nursing Education, 49, 687-690. http://dx.doi.org/10.3928/01484834-20100831-06

Committee on Information Technology Literacy, National Research Council (1999). Being Fluent with Information Technology. Washington DC: National Academy Press.

Edwards, G., Kitzmiller, R. R., \& Breckenridge-Sproat, S. (2012). Innovative Health Information Technology Training. CIN: Computers, Informatics, Nursing, 30, 104-109. http://dx.doi.org/10.1097/ncn.0b013e31822f7f7a

Edwards, J., \& O’Connor, P. A. (2011). Improving Technological Competency in Nursing Students: The Passport Project. The Journal of Educators Online, 8, 1-20.

Eley, R., Fallon, T., Soar, J., Buikstra, E., \& Hegney, D. (2008). The Status of Training and Education in Information and Computer Technology of Australian Nurses: A National Survey. Journal of Clinical Nursing, 17, 2758-2767. http://dx.doi.org/10.1111/j.1365-2702.2008.02285.x

Fedynich, L. V. (2014). Teaching beyond the Classroom Walls: The Pros and Cons of Cyber Learning. Journal of Instructional Pedagogies, 13, 1. http://www.aabri.com/manuscripts/131701.pdf

Fetter, M. S. (2008). Enhancing Baccalaureate Nursing Information Technology Outcomes: Faculty Perspectives. International Journal of Nursing Education Scholarship, 5, 1-15. http://dx.doi.org/10.2202/1548-923X.1440

Fetter, M. S. (2009a). Collaborating to Optimize Nursing Students’ Agency Information Technology Use. CIN: Computers, Informatics, Nursing, 27, 354-362.

Fetter, M. S. (2009b). Curriculum Strategies to Improve Baccalaureate Nursing Information Technology Outcomes. Journal of Nursing Education, 48, 78-85. http://dx.doi.org/10.3928/01484834-20090201-06

Flood, L. S., Gasiewicz, N., \& Delpier, T. (2010). Integrating Information Literacy across a BSN Curriculum. Journal of Nursing Education, 49, 101-104. http://dx.doi.org/10.3928/01484834-20091023-01

Lim, D. H., Morris, M. L., \& Kupritz, V. W. (2007). Online vs. Blended Learning: Differences in Instructional Outcomes and Learner Satisfaction. Journal of Asynchronous Learning Network, 10, $27-42$.

McNeil, B. J., Elfrink, V. L., Bickford, C. J., Piece, S. T., Beea, S. C., Averill, C., \& Klappenback, C. (2003). Nursing Information Technology Knowledge, Skills, and Preparation of Student Nurses, Nursing Faculty, and Clinicians: A U.S. Survey. Journal of Nursing Education, 42, 341-349.

National League for Nursing (2008). Preparing the Next Generation of Nurses to Practice in a Technology-Rich Environment: An Informatics Agenda.

https://www.google.com/url?sa=t\&rct=j\&q=\&esrc=s\&source=web\&cd=1\&cad=rja\&uact=8\&ved=0CB8QFjAAahUKEwj1q bHq04DHAhWKGJIKHVmkAE4\&url=http\%3A\%2F\%2Fwww.nln.org\%2Fdocs\%2Fdefault-source\%2Fprofessional-develo pment-programs\%2Fpreparing-the-next-generation-of-nurses.pdf\%3Fsfvrsn\%3D6\&ei=IPG4VfWZF4qxyATZyILwBA\&us g=AFQjCNEJ1eM0eii34jyL9PQn4YpOgK8RJg\&sig2= uHbYk6B6mIn7QnxMp9C-Q\&bvm=bv.98717601,d.aWw

Patterson, R., Carter-Templeton, H., \& Russell, C. (2009). Information Literacy: Using LISTEN Project Strategies to Equip Nurses Worldwide. Studies in Health Technology and Informatics, 146, 652-656. 
Saranto, K., \& Hovenga, E. J. S. (2004). Information Literacy-What It Is about? Literature Review of the Concept and the Context. International Journal of Medical Informatics, 73, 503-513. http://dx.doi.org/10.1016/j.ijmedinf.2004.03.002

Shapiro, J. J., \& Hughes, S. K. (1996). Information Literacy as a Liberal Art: Enlightenment Proposals for a New Curriculum. Educom Review, 31. http://net.educause.edu/apps/er/review/reviewArticles/31231.html

Sherman, H., Comer, L., Putnam, L., \& Freeman, H. (2012). Blended versus Lecture Learning: Outcomes for Staff Development. Journal of Nurses in Staff Development, 28, 186-190. http://dx.doi.org/10.1097/NND.0b013e31825dfb71

Skiba, D. J., Connors, H. R., \& Jeffries, P. R. (2008). Information Technologies and the Transformation of Nursing Education. Nursing Outlook, 56, 225-230. http://dx.doi.org/10.1016/j.outlook.2008.06.012

Stombaugh, A., Sperstad, R., VanWormer, A., Jennings, E., Kishel, H., \& Vogh, B. (2013). Using Lesson Study to Integrate Information Literacy throughout the Curriculum. Nurse Educator, 38, 173-177.

http://dx.doi.org/10.1097/NNE.0b013e318296db56 


\section{Appendix}

\section{Questions Asked about Students' Perception and Satisfaction with Blended-Learning/Teaching.}

\section{Perceptions of blended-learning/teaching}

I feel more comfortable in an online educational setting.

I think that same content was covered in hybrid online format as would have been in traditional lecture format.

Good computer ability as a prerequisite for the online class is important.

Complexity of tasks required in the online class is important.

Selecting a good group partner is important in the online class.

Regular preparation for the online class is important.

Use various communication media available in the online class is important.

Participating in the variety of discussion options available in the online class is important.

My individual interest in the topics presented in the online class is important.

Collaborative learning is effective in the online class.

\section{Effectiveness of blended-learning/teaching}

Allows knowledge building.

Promotes in-depth and advanced learning.

Allows building computer skills.

Ensures that students are engaged and motivated in learning.

Encourages collaborative (group) learning.

Enables effective communication with the teacher and peers.

Helps lifelong learning.

Promotes self-learning.

\section{After completing the course, I}

Am more familiar with and capable of using various learning programs such as e-campus.

Understand more about information literacy and its framework.

Can explain clearly terms related to information literacy.

Know how to apply information literacy skills in nursing.

Can effectively use e-books, e-journals, world web wide, and information sources in library.

Can organize and manage information more effectively.

Can use various information technology tools to present nursing information. 